\title{
Tool temperature and cutting forces during the machining of particleboard and solid wood.
}

\begin{abstract}
A series of machining experiments were carried to determine the tool edge temperature and cutting forces when cutting particleboards and solid wood. The experiments were carried out using a specially designed high speed lathe with cemented tungsten carbide tools, which machined a rotating disc of the experimental materials. The cutting forces were measured using a piezoelectric load cell, while the cutting temperature was recorded through thermocouples, specially attached to the knife inserts. The particleboards used in this study were made from oil palm empty fruit bunches and rubberwood, while solid rubberwood was the solid wood specimen. The results showed that the increase in principal cutting forces had a similar pattern with the temperature increase at the tool edge, implying a direct relationship between cutting forces and tool temperature. The cutting temperatures of $196^{\circ} \mathrm{C}$ for particleboard and $127^{\circ} \mathrm{C}$ for the solid wood, suggests that tool temperatures are lower than the temperatures at the cutting zone in the work-piece. Further, this study also proves that the possibility of electrochemical mechanisms on the wear of cemented tungsten carbide tools is limited, but the temperatures recorded at the tool edge are sufficient to accelerate the mechanical-abrasive wear of such tools. Nevertheless, the results of the study imply that the development of special cemented tungsten carbide cutting tools is deemed necessary for the cutting of particleboards to ensure its process economics.
\end{abstract}

Keyword: Machining; Particleboard; Solid wood; Tool-wear; Oxidation; Mechanicalabrasive wear. 